
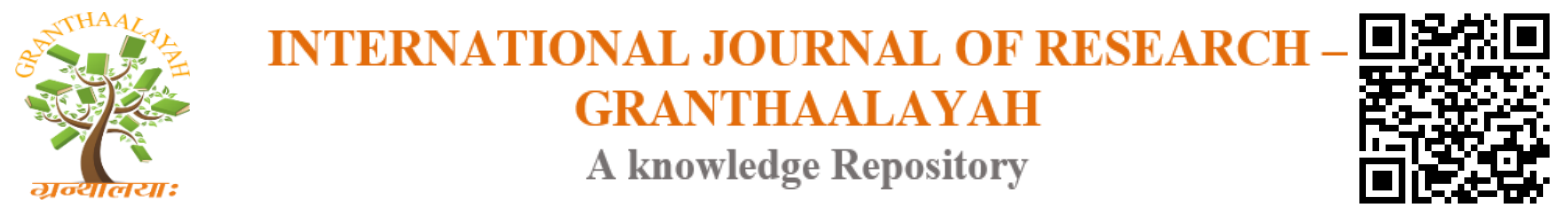

Social

\title{
A LITERATURE REVIEW ON MATERNAL MIGRATION: CASES OF CHINA, SRI LANKA, GUATEMALA, PHILIPPINES, AND POLAND
}

\author{
Jeany Rose Teguihanon ${ }^{1}$, Ginbert Permejo Cuaton ${ }^{2}$ \\ ${ }^{1}$ UNFPA, Manila, Philippines \\ ${ }^{2}$ Social Science Unit, Leyte Normal University, Philippines
}

\begin{abstract}
The increasing and enhanced migration over borders amplified the interdependency between countries making it as one of globalization's greatest indicator. The study of migration and its patterns involves analyzing different forces at play, in particular, the causes and impacts on the sending and receiving countries. Anchored on a qualitative research design, the data from secondary sources were gathered through desk research, and organized and analyzed using thematic analysis. This study takes an in-depth discussion and analysis of the degree and impacts of maternal labor migration, specifically in the countries of China, Sri Lanka, Guatemala, Philippines and Poland. Findings demonstrate that the increase of 'feminization' of labor emigration has brought about concerns over the 'crisis of care' when women and mothers leave. The focus on the impact of mother's migration is in relation to the perception that although maternal migration has positive effects, i.e. improved livelihood income due to remittances, it could also present complex negative impacts to the welfare of families and children left behind.
\end{abstract}

Keywords: Maternal Migration; Labor Migration; Care Chain; Migration; Philippines; Sri Lanka; China; Guatemala; Poland.

Cite This Article: Jeany Rose Teguihanon, and Ginbert Permejo Cuaton. (2019). "A LITERATURE REVIEW ON MATERNAL MIGRATION: CASES OF CHINA, SRI LANKA, GUATEMALA, PHILIPPINES, AND POLAND." International Journal of Research Granthaalayah, 7(3), 17-29. https://doi.org/10.29121/granthaalayah.v7.i3.2019.939.

\section{Introduction}

The increasing and enhanced migration over borders amplified the interdependency between countries making it as one of globalization's greatest indicator (Hessle, 2007). The movement of people across borders for work is considered as a continuous global trend that plays an important role in the globalized economies of the 21 st century, creating a complex web of connections and transactions between the Global South and the Global North (Graham et al., 2012). It is described either as an avenue to the enhancement of the standard of living or as the result of the imposition of aggressive capitalism and cultural homogenization (Healy, 2008). 
The study of migration and its patterns involves analyzing different forces at play, in particular, the causes and impact on the sending and receiving countries. Although causes for migration may be easier to pinpoint, understanding its impact and attempting to mitigate the causes may not be easy. Recognizing the relationship between various disciplines: human rights, economic, political, socio-cultural perspectives, will enable scholars, governments, and social welfare professionals to comprehend the causes of migration and construct meaningful and appropriate interventions (Yanovich, 2013).

Labor migration is considered as one of the results of globalization, its impact is mostly measured in economic terms as individuals and or families because they migrate to developed countries in search for better economic opportunities. As globalization continues and expands, the declining birth rates and increasing aging population has increased the demand for foreign labor. In recent years, children with one or both parents abroad can be found in various countries and big cities worldwide. There are many difficulties in correctly estimating the number of children affected by the out-migration of one or both parents because varying calculation methods are being utilized by national statistics which makes international comparisons challenging. (Cortes, 2007). However, the country-level studies cited by UNICEF highlights the extent of the impact of migration on children: around 1 million Sri Lankan children are left behind by labor migrant mothers (Save the Children, 2006), and an estimate of 9 million Filipino children under the age of 18 are left behind by one or both parents working abroad (Castaneda and Buck, 2012).

Given these conditions, this study will take an in-depth discussion and analysis of the degree and impacts of maternal labor migration, specifically in the countries of China, Sri Lanka, Guatemala, Philippines and Poland. The paper also discusses the impact of maternal migration on families and children left behind, remittances, family welfare and children's welfare.

\section{Materials and Methods}

Anchored on a qualitative research design, the data used in this research were obtained from secondary sources through desk research, and organized and analyzed using thematic analysis. Thematic analysis is applied in qualitative, quantitative, and sometimes mixed modes of research frameworks and employs a wide range of analytical techniques to generate findings and put them into context. It is a systematic, rigorous approach to analyzing documents obtained or generated in the course of research (White, M. \& Marsh, E., 2006; Downe-Wamboldt, 2009; and Hsieh and Shannon, 2005).

\section{Results and Discussions}

\subsection{Women and Feminization of Labor Migration}

Below is an analysis of the situation of women, families, and children in the context of labor migration. The analysis discusses the importance of mothers in the family based on societal expectations from various cultural contexts. The study chose to focus on the emerging role of women in migration and how this phenomenon affects traditional family dynamics from the perspective of selected countries. It aims to provide background and summarize key issues related 
to women labor migration from the countries of China, Sri Lanka, Guatemala, Philippines and Poland.

Migration plays a significant role in livelihood strategies for improving well-being. Although women are increasingly dominating migration patterns in Latin America as well as Europe (Sundari, 2007), migration is often regarded as male-centered, resulting in neglect and bias and for female migration to be overlooked. Only a few studies present the current realities of female migration: economic gains are minimal, development in communication, transportation and job market have increased the value of women in another arena, outside the home and making them able to earn an income without the need to cut family ties. This provides women a sense of selfworth, greater power, and status, which on the other hand can cause issues and constraints within the family (Sundari, 2007).

In various countries in Asia, Middle East, and Europe, women are often employed as domestic workers or other related works. Although remittances from women migrants contribute to the sending country's economy, the social costs of female migration are also considerable (Sundari, 2007). Research conducted on the feminization of migration often define the phenomenon in terms of the increase in the number of women in the migration stream (Vause and Toma, 2015). It is defined as a process where "international migrant streams formerly dominated by men gradually become gender-balanced or even majority-female" (Alexander and Steidl, 2012) or when women plays an "increasing part in all regions and in all types of migrations" (Castles and Miller,1998). The change in the gender composition of migration occurs due to the increase in the level of mobility of women or the decrease in the numbers of male migrants. This also includes the increasing active participation of women in the labor force, rather than being dependent on their male counterparts. As cited by Verschuur (2013) and Oishi (2002), the feminization of migration is a process where women are migrating as independent or autonomous individuals for job opportunities and not as dependent on their families or husbands (Vause and Toma, 2015).

The International Labor Organization (2015) estimates that 150 million international migrants are migrant workers and women account for 66.6 million or 44 percent which varies across regions: Asia with 42 percent, 52.4 percent in Europe and 51.2 percent in Northern America. The lower percentage of women in Asia resulted in the recent large and rapid increase in the number of male migrant workers in the oil-producing countries of Western Asia, while the higher proportion of women in Europe and America was mainly the outcome of the aging population of the migrants who arrived earlier in those areas (UNDESA, 2016).

One of the impacts of the increasing feminization of overseas labor migration in recent decades is about the "crisis of care" the occurs when women and mothers leave (Parreñas, 2005). This shows the constant impact of gender roles and identities amid potential disruption brought about by the migration of mothers to become breadwinners for the family while the fathers and children are left behind (Graham, et al., 2012). The focus on the impact of mother's migration is in relation to the perception that although there are positive implications for a mother's migration, it also leads to multidimensional negative implications (Arunatilake, et al., 2010; De and Ratha, 2012; Perera and Jampaklay, 2011; Senaratna, 2012; and Weeraratne, 2016). 
The ideology of domesticity or 'moral motherhood'- self-sacrificing, passionless, devoted to the maintenance of 'haven in a heartless world'- became important in claiming of the women's superiority role to men (Davis et al., 2010). The growth of the service employment has been popular among women as they have the attributes: empathy, nurturing relationships, etc.- that are essential in this economy (Davis et al., 2010). The transformation of domesticity arguably showed that women have claimed the equal access to employment, functional and pay flexibility.

\subsection{Country Study on Maternal Migration}

In this section, the authors analyzed data from secondary sources and presented the status and effects of female labor migration in the countries of China, Sri Lanka, Guatemala, Philippines and Poland. The selection of these countries was based on the nationalities of the authors' colleagues when they were still studying at the University of Warsaw in 2016-2017 as scholars of the Erasmus Mundus program of the European Union.

\subsection{The Case of China}

China's internal migration involves rural residents migrating to urban areas for more industrialized jobs. The decrease of work opportunities in the agricultural sector and expanding industrial and service sector employment in urban cities have compelled 150-180 million rural workers to find employment in urban areas (People's Daily Online, 2004). In 2003, reports have shown that female comprises $49 \%$ of migrants who are registered outside their native community, indicating a substantial increase from the often-cited proportion of one-third. This is attributed to the higher demand for cheaper cost of labor by young women in manufacturing industries and the growing acceptance for young women to contribute to household income (Tuñón, 2006).

The large-scale migration caused by rapid industrialization resulted in structural and institutional changes, thus, loosening of restrictions on labor mobility has encouraged people to move to places, live and work in cities if they chose to (Démurger and $\mathrm{Xu}, 2015$ ). Although labor mobility has increased, the strong institutional constraints imposed by the household registration system (Hukou) shaped the pattern of migration which is dominated by temporary migration. The Hukou system requires citizens to be registered per place of permanent resident and occupation (agricultural vs non-agricultural) and are provided access to jobs and rights to social welfare and benefits which include the provision of education for children. Thus, parents often migrate to the city and leave their children behind in the care of grandparents or other relatives in their home communities (All China Women's Federation, 2013). To end, data cited by UNICEF (2014) show that there are approximately 61 million children left behind under the age of 17 in China's rural communities.

\subsection{The Case of Sri Lanka}

Sri Lanka is considered one of the leading labor-sending countries in Asia and foreign employment has become the largest source of foreign exchange in its economy during the past few years. With a population of 21.2 million (PRB, 2016), a total of 263,307 persons (males 66\%, females 34\%) left for foreign employment in 2015 (SLBFE, 2015). The female International Labor Migrants (ILM) have increased over ten years with $81 \%$ of female migrants employed as domestic 
housemaids in the Middle East. The government has encouraged the migration of domestic workers "as part of a deliberate strategy to alleviate poverty, reduce unemployment and generate access to hard currency" (Frantz, 2013). The government benefits from foreign employment revenues as the main source of foreign currency income for the country while the migrants from the middle east contribute 54\% of all remittances in 2015 (SLBFE, 2015).

Sri Lankan women who migrate for foreign employment migrate before the age of thirty-five (54\%), which is considered as "reproductive, child bearing and child rearing age" (ILO, 2013). It was noted that in 2010, most of the more than one million women migrants from Sri Lanka have children left behind, half of whom are under six years of age. Like all migrant workers, Sri Lankan women leave their families for various interconnecting factors: unemployment, poverty, desire for better access to education and health care for families, and repayment of debts (Rosewarne, 2012). Sri Lankan women have higher unemployment rates than men $(6.4 \%$ is to $2.8 \%)$ while labor force participation is less than half the rate of men (34.7\% is to $74.4 \%)$. Due to the rising cost of living, low income and low-skilled women are forced to migrate for work to support their families. The lower levels of education of women limit their opportunities to find employment in Sri Lanka which results in skilled migration. However, despite the economic benefits of remittances for ILMs, research shows that negative impacts in the socio-cultural and health aspects are greater than the positive outcomes (Jayasuriya and Opeskin, 2015).

\subsection{The Case of Guatemala}

Guatemala's large-scale international migration is considered as a response to multiple internal problems in the country. With a population of about 14 million, the country's emigrant stock is 871,900 which is $6.1 \%$ of the population. Top countries of emigration include United States, Mexico, Belize, Canada, El Salvador, Spain, Costa Rica, Honduras, France, and Nicaragua (World Bank, 2011). The various factors for emigration include lack of economic opportunities, natural disasters, increasing social violence and political instability (Jonas, 2013).

Due to the plethora of problems in Guatemala, people become desperate to be able to escape poverty and provide the needs of their families: health care, education, shelter, etc. In this desperation, they decide to emigrate from Guatemala, usually northward to the United States. However, getting to the United States may not be easy for all immigrants. They are exposed to different kinds of exploitation and abuse especially by human smugglers commonly known as "coyotes" (OpenBorder, n.d.). Guatemalans pay a huge amount of money for their voyage and become deeply in debt to the coyotes who do not provide any guarantee for their safe entry to the United States. They are exposed to high risk of deportation and exploitation where women are at risk of sexual abuse. Furthermore, once they cross the border, they are left to fend for themselves without water and food for long periods of time (Smolarek, 2007).

Although most Guatemalan migrants are of working age males, the growing poverty among families has also led to the increasing number of female migrants and the "feminization" of emigration in Guatemala. One of the reasons is the high unemployment and underemployment of women. The growing number of women moving northward for work as a household livelihood strategy is mostly single mothers or heads of family. They rely on remittances as an integral part 
of maintaining their family's needs back at home (Davis and Brazil, 2016; Smith, 2006; and Jonas, 2013).

As the economic migration to Mexico continues, 500,000 Guatemalans travel to Chiapas, a southern Mexican state bordering Guatemala, every year for temporary work. The women work as house helpers, small-scale traders, or prostitutes while waiting for opportunities to move further north (Smith, 2006). Unfortunately, while in the migration process through Mexico, women are vulnerable to gendered violence such as rape, forced recruitment, and sex slavery. Because of these risks, women take contraceptive measures to protect themselves from unintended pregnancies and sexually transmitted diseases (Jonas, 2013).

For women who arrived in the United States and avoided deportation, they have demonstrated the ability to find steady but low-income jobs. The migrant mothers who are responsible for their children's upbringing have provided continuous interaction with their children and other networks in the community. The continuity of care enabled parents and their children left behind in the home country to establish strong connections and a sense of independence and positive self-identity for the migrant mothers (Jonas, 2013).

\subsection{The Case of the Philippines}

Migration in the Philippines is primarily driven by poverty and the need to explore other sources of livelihood and nearly every Filipino family has a family member or relative that worked or is working abroad. According to the Philippine Statistics Authority (2015), there is a total of 2,447,000 Filipinos (51\% female and 49\% male) who left the country with an average of 6,092 leaving the country every day (Migrante International, 2015). The labor migration from the country is largely demand or market-driven where private recruitment agencies dominate and the state promotes a facilitative role through export-oriented policies (Briones, 2009; Eviota, 2004; and Van der Ham et al., 2014). Philippines is considered as the $4^{\text {th }}$ lead labor exporter in the world where the majority of the migrants are working in the Gulf countries: Saudi Arabia, United Arab Emirates, and Qatar (ABS-CBN, 2015). Although the occupational profile of Overseas Filipino Workers (OFW) cuts across various categories, identified top occupations include seafaring sector, household service workers, nurses, food industry workers (waiters, bartender, etc.), caregiver and caretakers, cleaners, and other related workers (ABS-CBN, 2015). Granting the market demands for less skilled occupations, most OFWs have completed more advanced level of education that is more than what is required for their line of work. This also led to questions about the prospect of brain wastage/ brain-drain instead of brain gain when educated OFWs land less skilled occupations abroad (ABS-CBN, 2015 and IOM, 2013).

While the labor migration is still considered a male-dominated field, a growing number of new migrants or workers with new job contracts are women. The new migration trend that is dominated by younger female migrant workers is a function of new market demands. Due to intensified globalization, government policies, changing role of women in receiving countries, and lack of economic opportunities in the home country, Filipino women have started to work abroad in increasingly large numbers (Encinas-Franco, 2016). 
This gendered transformation was brought about by the demand for domestic workers in more developed countries. This is based on the gendered transformation of occupations where women are perceived as docile, nimble and weak (Tigno, 2014). As domestic work is often not considered "formal work" due to its irregular work hours and stay-in nature. This exposes domestic workers to vulnerable working conditions and impacts their emotional well-being. Issues cited include homesickness, exploitation by employers, and over-worrying about their families back at home (Van der Ham et al., 2014).

Due to the feminization of migration, changes in gender roles has been essential to fill the void left by the migrant mother. It has been considered as 'transformative' for the family as mothers need to leave their families and take up employment abroad while fathers are left to take on the role of the mother. In the Philippine context, fathers are considered as the "pillars of the home"- main breadwinner or provider of the family -an essential factor of men masculinity. The women as the "light of the home" are tasked to take care of the family and because of the new dynamics, they are forced to leave behind their role as mothers and become paid employees that may generate income more than their husbands' (IOM, 2013).

\subsection{The Case of Poland}

In Europe, approximately 500,000 children are considered 'left behind' or children who have at least one parent abroad. In countries along the Baltic Sea coast, including Poland, between 1.1 to 1.6 million children aged 9-18 years old experienced some separation from at least one parent within a three-year period (Ruin, 2014; and Yanovich, 2013). A child with said background has become known in media as "Euro-orphan" (Euro-sierota in Polish) - a child left behind while parents go abroad to work. Although the phenomenon has been present from the era before Poland joined the European Union (EU) in 2004, it has continued to grow since the 2004 EU enlargement (Connoly, 2015 \& Urbanska, 2009).

The free movement of labor is central to the European Community and is considered as one of the essential pillars of economic integration in the EU, alongside the freedom of mobility of capital, goods, and services. The free labor mobility enabled EU citizens to pursue employment opportunities with any attached social benefits in other EU member states (Kahanec, 2012; and Barslund et al., 2014). The 2004 and 2007 EU enlargement increased the freedom of movement to workers from the twelve new member states mainly from Central Eastern Europe (Kahanec, 2012). As the floodgates open for migration of people across geographic borders, the number of migrants leaving their home country has increased over the years. Motivations for leaving one's origin country to a different country involves "push" and "pull" factors ranging from unfavorable conditions in home countries e.g. lack to no available economic opportunities, to alleged more promising circumstances in the country of destination e.g. educational opportunity, better employment opportunity and better wages (Solheim \& Ballard, 2016).

Emigration is one of the most distinguishing features of Polish society. Before the 2004 EU enlargement, unemployment in Poland reached its post-communist peak of 20.6\% (GUS, 2009), making it a major 'push factor' for migration to Western Europe. Following the EU ascension in 2004, the wave of migration began and was amplified by the expiration of restrictions on Polish migration in 2011. Per data released by the Central Statistical Office (GUS, 2013) 2.2 million Poles 
lived for more than three months abroad in 2013. That figure is marginally lower than the recorded 2.3 million in 2007, after which some people started to move back.

To understand the context of Poland's feminization of migration, we must discuss the structural context of gender in the country. Although the state is committed to the promotion of gender equality and emancipation, traditional understanding of gender and gender roles in the family has remained even after the inclusion of women in the labor market (Heinen and Wator, 2006). Women are encouraged to focus on family life than employment (Hryciuk, 2017). Furthermore, after the EU accession, the state continued to promote the conservative discourse despite the diplomatic pressure by the EU (Regulska and Grabowska, 2008). Nevertheless, changes in gender expectations have been continuing and women's role is now explored more than just being a homemaker and mother (Budrowska, 2005 and Titkow, 2007). In addition to the state, the Roman Catholic church's influence on gender issues has been visible (Heinen and Wator, 2006). Church representatives often perceive the role of women as that of a homemaker and do not promote employment outside of the home (Hryciuk, 2017). This is in support of the Catholic teachings that are "distant from feminist ideas of gender equality" (Dabrowska, 2004).

Until the end of the 1990s, emigration was the families' strategy to enhance their struggling economic situation. However, motivations of women have begun to change over the next few years following Poland's EU accession. Research suggests the existence of two categories of emigrant women: women with families- aged 30-45 years old are driven by family's economic situation, while single women are motivated to explore new opportunities and start a new life departing from the Polish traditionalist environment (Grzymała-Kazłowska, 2001). Further research is categorized by stronger influences to gender studies. They now shifted its focus to gender and its two-fold influences in emigration: the greater emancipation of women and the aspect of 'double oppression' (migration as a family life strategy) which resulted in fewer opportunities for employment and the continuation of existing traditionalist gender ideologies (Slany and Malek, 2006).

\section{Conclusions}

The interest on the social aspects or impact of migration is brought about by the emerging trends on the feminization of labor migration, and the impact of migration and remittances on families and children left behind. Although some research on children left behind is available, there is a need for a more careful study to address the issues that left-behind children and families face upon a parent especially a mother's departure. While migrants travel to foreign countries to work in the hopes of being able to improve the well-being of their family and provide better opportunities for their children, the findings of previous researches show that the absence of a mother may be more detrimental to the psychosocial development of the child.

Studies conducted by Cortes (2010), Antman (2013), Lahaie et al. (2009) and Jampaklay (2006) presented the negative impact of maternal migration. It is held that a mothers' absence is more harmful to children's education and psycho-social behavior compared to that of fathers. This is brought about by the phenomenon or characteristic related to contemporary parental emigration called "feminized/ feminization of migration" (Lutz and Palenga-Mollenbeck, 2012). The increase of 'feminization' of labor emigration has brought about concerns over the 'crisis of care' when women and mothers leave (Parreñas, 2005). The migration of mothers to become the breadwinner 
of the family poses a potential disruption or impact on their perceived (gender) roles and identities to their families and children left behind (Graham, et al., 2012). Simply put, the focus on the impact of mother's migration is in relation to the perception that although maternal migration has positive effects, i.e. improved livelihood income due to remittances, it could also present complex negative impacts to the welfare of families and children left behind (Arunatilake, et al., 2010; De and Ratha, 2012; Perera and Jampaklay, 2011; Senaratna, 2012; and Weeraratne, 2016). With a special focus on the role of women in the family and the increasing trend of feminization of labor, children may assume responsibilities left behind by mothers to help the remaining parent or another caregiver, who is left to take care of the needs of the children.

\section{Acknowledgements}

The authors are grateful to the advisers and peer-critiques of this paper as well as to the administrators and faculty members of the University of Warsaw in Poland for their support.

\section{References}

[1] Alexander, J. and Steidl, A. (2012). Gender and the "Laws of Migration": A Reconsideration of Nineteenth-Century Patterns. Social Science History, 36(2), pp.223-241.

[2] All China Women's Federation (2013). Report on rural left-behind children and urban migrant children.

[3] Antman, F. (2013). The impact of migration on family left behind. In: A. Constant and K. Zimmermann, ed., International handbook on the economics of migration. Cheltenham, UK: Edward Elgar Publishing.

[4] Arunatilake. N, Jayaratne.S, Jayawardena.P, Jayaweera. R, Weerakoon. D. (2010). "Impact of Remittances on the Household of the Emigrant and on the Economy of the Migrant's Country: Sri Lanka", Project Report Submitted on 10th Round Regional Research Competition of South Asia Network of Economic Research Institutes.

[5] Barslund, M., Busse, M., Vargas-Silva, C., Kaczmarczyk, P., Baas, T., Peinado, M., Jimeno, J., Lacuesta, A., Galgóczi, B. and Leschke, J. (2014). Labour mobility in the EU: Dynamics, patterns and policies. Intereconomics, [online] 49(3), pp.116-158. Available at: https://www.ceps.eu/system/files/IEForum32014.pdf [Accessed 4 Feb. 2017].

[6] Briones, L. (2009). Empowering migrant women: Why agency and rights are not enough. Surrey, UK: Ashgate Press.

[7] Budrowska, B. (2005). Nieodplatna praca kobiet i próby jej wyceny [Unpaid women's work and the attempts to put a price on it]. [online] Docplayer.pl. Available at: http://docplayer.p1/5494536Nieodplatna-praca-kobiet-i-proby-jej-wyceny.html [Accessed 29 May 2017].

[8] Castaneda, E., and Buck, L. (2012) Remittances, Transnational Parenting, and the Children Left Behind: Economic and Psychological Implications. Available at http://www.childmigration.net/Main_theme_home?selection=Children_left_behind [accessed 4 Jan 2017]

[9] Castles, S. and Miller, M. (1998). The Age of Migration: International Population Movements in the Modern World. London: Palgrave Macmillan.

[10] Connoly, K. (2015). As Poland loses its doctors and builders, 'Euro-orphans' are left at home to suffer. The Guardian. [online] Available at: https://www.theguardian.com/world/2015/mar/15/euro-orphans-fastest-shrinking-town-polandradom [Accessed 11 Feb. 2017]. 
[11] Cortes, P. (2010), 'The feminization of international migration and its effects on the children left behind: evidence from the Philippines', Working Paper, Boston University School of Management, MA.

[12] Cortes, R. (2007). Children and women left behind in labor sending countries: an appraisal of social risks. [ebook] Global Report on Migration and Children. Available at: http://www.childmigration.net/files/Rosalia_Cortes_07.pdf [Accessed 11 Feb. 2017].

[13] Dabrowska, M. (2004). Whose Interests Do They Defend? Problems of the Polish Feminist Movement.. [online] GendeRomania. Available at: https://www.atria.nl/epublications/2005/gendeRomania.pdf [Accessed 29 May 2017].

[14] Davis, J. and Brazil, N. (2016). Migration, Remittances and Nutrition Outcomes of Left-Behind Children: A National-Level Quantitative Assessment of Guatemala. PLOS ONE, 11(3), p.e0152089.

[15] Davis, K., Evans, M. and Lorber, J. (2010). Handbook of gender and women's studies. London: Sage.

[16] De, P. and Ratha, D. (2012). Impact of remittances on household income, asset and human capital: evidence from Sri Lanka. Migration and Development, 1(1) 163-179.

[17] Démurger, S. and Xu, H. (2015). Left-behind children and return migration in China. IZA Journal of Migration, 4(1), pp.1-21.

[18] Downe-Wamboldt, B. (2009). Content Analysis: Methods, applications and issues. Health Care for Women International. Vol 13, Issue 3, pp 313-321. https://doi.org/10.1080/07399339209516006

[19] Frantz, E. (2013). Jordan's Unfree Workforce: State-Sponsored Bonded Labour in the Arab Region, DEV. STUD. 49 (J), pp. 1072-1075

[20] Encinas-Franco, J. (2016). Filipino Women Migrant Workers and Overseas Employment Policy: An Analysis From Women's Rights Perspective. Asian Politics \& Policy, 8(3), pp.494-501.

[21] Eviota, E. U. (2004). The context of gender and globalization in the Philippines. In D. Aguilar, \& A. Lacsamana (Eds.) Women and globalization (pp. 52-67). New York, NY: Humanity Books.

[22] Glowny Urza d Statystyczny [GUS] [Central Statistical Office]. (2009). Unemployment in the years 1990_2009. In A. White (2010) Young people and migration from contemporary Poland. Journal of Youth Studies, 13(5) 565-580.

[23] Glowny Urza d Statystyczny [GUS] [Central Statistical Office]. (2013). Rocznik Statystyczny Rzeczypospolitej Polskiej 2013. Available at: https://stat.gov.pl/obszary-tematyczne/rocznikistatystyczne/roczniki-statystyczne/rocznik-statystyczny-rzeczypospolitej-polskiej-2013,2,8.html [Accessed October 2018].

[24] Graham, E., Jordan, L., Yeoh, B., Lam, T., Asis, M., and Su-Kamdi (2012). Transnational Families and the Family Nexus: Perspectives of Indonesian and Filipino Children Left behind by Migrant Parent(s). Environment and Planning A, 44(4), pp.793-815.

[25] Grzymała-Kazłowska, A. (2001) A challenge of transition: Polish migrant women in Brussels, Ethnographica, 1(1): 46-55

[26] Healy, L. (2008). International social work. Oxford: Oxford University Press.

[27] Heinen, J. and Wator, M. (2006). Child Care in Poland before, during, and after the Transition: Still a Women's Business. Social Politics: International Studies in Gender, State \& Society, 13(2), pp.189-216.

[28] Hessle, S. (2007). Globalisation: Implications for International Development Work, Social Work and the Integration of Immigrants in Sweden. In: L. Dominelli, ed., Revitalising communities in a globalising world, 1st ed. Aldershot: Ashgate, pp.231-241.

[29] Hryciuk, R. (2017). Political Motherhood in Poland: The Emergence of Single - Mothers for the Alimony Fund Movement. [online] Center for Global Justice. Available at: http://www.justiciaglobal.mx/wp-content/women3.pdf [Accessed 29 May 2017].

[30] Hsieh, H. and Shannon, S. (2005). Three Approaches to Qualitative Content Analysis. SAGE Journals. https://doi.org/10.1177/1049732305276687 
[31] ILO. (2015). ILO global estimates on migrant workers: Results and methodology. Special focus on migrant domestic workers. [online] Available at: http://www.ilo.org/wcmsp5/groups/public/--dgreports/---dcomm/documents/publication/wcms_436343.pdf [Accessed 15 Jun. 2017].

[32] ILO. (2013). REINTEGRATION WITH HOME COMMUNITY: PERSPECTIVES OF RETURNEE MIGRANT WORKERS IN SRI LANKA [online] Available at:

http://www.ilo.org/wcmsp5/groups/publicasia/ro-bangkok/-ilo-

colombo/documents/publication/wcms_233365.pdf [Accessed 15 Jun. 2017].

[33] IOM. (2013). Country Migration Report: The Philippines 2013. [ebook] Makati City: International Organization for Migration. Available at:

https://www.iom.int/files/live/sites/iom/files/Country/docs/CMReport-Philipines-2013.pdf

[Accessed 28 May 2017].

[34] Jampaklay, A. (2006), 'Parental absence and children's school enrolment: evidence from a longitudinal study in Kanchanaburi, Thailand', Asian Population Studies, 2 (1), 93-110.

[35] Jayasuriya, R. and Opeskin, B. (2015). The Migration of Women Domestic Workers from Sri Lanka: Protecting the Rights of Children Left Behind. Cornell International Law Journal, 48, pp.579-538.

[36] Jonas, S. (2013). Guatemalan Migration in Times of Civil War and Post-War Challenges. [online] Migration Policy Institute. Available at: http://www.migrationpolicy.org/article/guatemalanmigration-times-civil-war-and-post-war-challenges [Accessed 27 May 2017].

[37] Kahanec, M. (2012). Labor Mobility in an Enlarged European Union. [online] Available at: http://ftp.iza.org/dp6485.pdf [Accessed 15 Jun. 2017].

[38] Lahaie, C., Hayes, J. A., Markham Piper, T. and Heymann, J. (2009). 'Work and family divided across borders: the impact of parental migration on Mexican children in transnational families', Community, Work and Family, 12 (3), 299-312.

[39] Lutz, H. and Palenga-Mollenbeck. E. (2012). Care Workers, Care Drain, and Care Chains: Reflections on Care, Migration, and Citizenship. Social Politics 19(1) 15-37.

[40] Migrante International. (2015). \#SONA2015 Number of OFWs leaving daily rose from 2,500 in 2009 to 6,092 in 2015. [online] Available at:

https://migranteinternational.org/2015/07/29/sona2015-number-of-ofws-leaving-daily-rose-from2500-in-2009-to-6092-in-2015/ [Accessed 28 May 2017].

[41] Oishi N. (2002). "Gender and migration: An integrative approach", University of California, San Diego, The Center for Comparative Immigration Studies, Working Paper 49.

[42] Parreñas, R. S. (2005). Children of Global Migration: Transnational Families and Gendered Woes. Palo Alto: Stanford University Press.

[43] People's Daily Online (2004). China to train 35 million rural workers in 7 years: official. [online] Available at: http://en.people.cn/200404/07/eng20040407_139731.shtml [Accessed 15 Jun. 2017].

[44] Perera, S., and Jampaklay, K. (2011) International Contract Migration and Children Left Behind: Impacts on children's School Enrolment in Sri Lanka, Sri Lanka. Journal of Population Studies, $12-13$.

[45] Philippine Statistics Authority (PSA). (2015). Statistical Tables on Overseas Filipino Workers $(O F W): 2015$ | Philippine Statistics Authority. [online] Available at:

https://psa.gov.ph/content/statistical-tables-overseas-filipino-workers-ofw-2015 [Accessed 28 May 2017].

[46] PRB. (2016). MAP. [online] Available at: http://www.worldpopdata.org/index.php/map [Accessed 15 Jun. 2017].

[47] Regulska, J. and Grabowska, M. (2008). Will it make a difference? EU Enlargement and Women's Public Discourse in Poland. In: S. Roth, ed., Gender Politics in the Expanding EU. Mobilization, Inclusion and Exclusion, 1st ed. Oxford: Berghahn Books, pp.137-154.

[48] Ruin, P. (2014). Children left behind [online] Available at: http://balticworlds.com/children-leftbehind/ [accessed 4 Jan 2017] 
[49] Save the Children (2006). Left behind, left out - the impact on children and families of mothers migrating for work abroad. 1st ed. [ebook] Sri Lanka: Save the Children. Available at: https://resourcecentre.savethechildren.net/node/8007/pdf/left_behind_left_out__the_impact_of_children_and_families_of_mothers_migrating_for_work_abroad.pdf [Accessed 1 Jun. 2017].

[50] Senaratna, B. (2012). Left-behind children of migrant women: Difficulties encountered and strengths demonstrated. Sri Lanka Journal of Child Health, 41(2).

[51] Slany, K. and Malek, A. (2006). Integration of new female migrants in Polish labor market and society and policies affecting integration: State of the Art. [ebook] Krakow,Poland: Working Paper No. 9 - WP4. Available at:

http://www.femipol.uni-frankfurt.de/docs/working_papers/wp3/Poland.pdf [Accessed 27 Feb. 2017].

[52] SLBFE. (2015). Overview: Recent Trends In International Migration. (n.d.). [online] Available at: http://www.slbfe.lk/file.php?FID=253 [Accessed 15 Jun. 2017].

[53] Smith, J. (2006). Economic Migrants Replace Political Refugees. [online] Migration Policy Institute. Available at: http://www.migrationpolicy.org/article/guatemalan-migration-times-civilwar-and-post-war-challenges// [Accessed 27 May 2017].

[54] Smolarek, B. (2007). Causes and Effects of Guatemalan Immigration to the United States. [ebook] Wisconsin: University of Wisconsin-La Crosse. Available at: https://www.uwlax.edu/urc/juronline/PDF/2007/smolarek.pdf [Accessed 28 May 2017].

[55] Solheim, C. and Ballard, J. (2016). Ambiguous Loss Due to Separation in Voluntary Transnational Families. Journal of Family Theory \& Review, 8(3) 341-359.

[56] Sundari, S. (2007). Migrant women and urban labour market. 1st ed. New Delhi: Deep \& Deep Publications.

[57] Rosewarne, S. (2013). Temporary International Labor Migration and Development in South and Southeast Asia. PP. 63-71. [online] Available at: http://asiapacific.unwomen.org/ /media/7148BD87A4F7412D8CBD10482146276F.ashx

[58] Tigno, J. (2014). At the Mercy of the market?: State-enabled, market-oriented labor migration and women migrants from the Philippines. Philippine Political Science Journal, 35(1), pp.19-36.

[59] Titkow, A. (2007). Tozsamosc polskich kobiet. Ciaglosc, zmiana i konteksty [Identity of Polish Women. Continuity, Change and Contexts]. Warszawa: IFiS PAN.

[60] Tuñón, M. (2006). Internal Labour Migration in China: Features and Responses. ILO Beijing. http://ilo.int/wcmsp5/groups/public/---asia/---ro-bangkok/---ilo-

beijing/documents/publication/wcms_158634.pdf [Accessed 17 May 2017].

[61] UNDESA. (2016). International Migration Report 2015. [ebook] New York: United Nations Department of Economic and Social Affairs. Available at:

http://www.un.org/en/development/desa/population/migration/publications/migrationreport/docs/ MigrationReport2015.pdf [Accessed 20 Mar. 2017].

[62] UNICEF. (2014). National Working Committee on Children and Women (NWCCW), and National Bureau of Statistics. Children in China: an atlas of social indicators 2014. United Nations Children's Fund, Beijing.

[63] Urbanska S. (2009). Matka migrantka. Perspektywa transnarodowos'ci w badaniu przemian ro'1 rodzicielskich. Studia Migracyjne Przegl ad Polonijny. 1, pp. 61-84.

[64] Van der Ham, A., Ujano-Batangan, M., Ignacio, R. and Wolffers, I. (2014). Toward healthy migration: An exploratory study on the resilience of migrant domestic workers from the Philippines. Transcultural Psychiatry, 51(4), pp.545-568.

[65] Vause, S. and Toma, S. (2015). Is the Feminization of International Migration Really on the Rise? The Case of Flows from the Democratic Republic of Congo and Senegal. Population, 70(1), pp.3964. 
[66] Verschuur, C. (2013). Theoretical debates on social reproduction and care: The articulation between the domestic and the global economy, in Oso Casas L., Ribas Mateos N. (eds), International Handbooks on Gender Series, pp. 145-161.

[67] Weeraratne, B. (2016). Protecting the Welfare of Children and its Causal Effect on Limiting Mother's Labour Migration. International Migration, 54(5) 59-75.

[68] White, M. D. and Marsh, E. E. (2006). Content Analysis: A flexible methodology. Library Trends 55(1), 22-45. Johns Hopkins University Press. Retrieved on October 11, 2018, from Project MUSE Database.

[69] World Bank. (2011). Migration and Remittances Fact book: Guatemala. Available at: http://siteresources.worldbank.org/INTPROSPECTS/Resources/3349341199807908806/Guatemala.pdf

[70] Yanovich, Y. (2013). Migration and development in context: The social and economic impact of labor migration on children left behind (Order No. 1525063). ProQuest.

*Corresponding author.

E-mail address: cuatonginbert@ gmail.com 